\title{
Importance of Generational Corporate Social Responsibility Perspective: A Literature Review
}

\author{
Megan Fixen \\ Minot State University
}

The corporate social responsibility concept (CSR) is attracting attention in the business environment. This paper includes a review of CSR and the importance of understanding generational perspective of CSR. Evidence suggests that integrating CSR into business strategy has an impact on a company's ability to attract and retain consumers. Literature revealed that implementing CSR initiatives results in benefits including building a favorable reputation and consumer loyalty. As a result, implementing CSR initiatives tailored to generational preferences might increase the ability of a business to realize the benefits previously listed. Therefore, understanding the perspectives of a specific generational market is meaningful.

Keywords: corporate social responsibility, marketing, consumer loyalty, reputation, increased profit, generational perspective

\section{SEARCH STRATEGY}

The purpose of this paper is to provide a comprehensive literature review of the importance of understanding generational perspective in the rapidly growing use of CSR in business practice. The literature review for this paper was from peer-reviewed publications on CSR, business reputation, consumer loyalty, reputation, and generational differences. The key terms consumer marketing, CSR, generational differences, reputation, and consumer loyalty guided the literature search for scholarly articles from EBSCOhost and Google scholar. Peer-reviewed journal articles located by the EBSCOhost and the Google scholar search engine provided the primary literature reviewed for this research. Several textbooks provided the background for the theoretical foundation and the key concepts and terms.

\section{INTRODUCTION}

Modern business leaders realize the important role that corporate social responsibility (CSR) plays in sustainability (Hategan, Sirghi, Curea-Pitorac, \& Hategan, 2018). CSR can be defined as "the economic, legal, ethical, and discretionary expectations that society has on organizations" (Carroll, 1979, p. 500). Esmaeilpour and Barjoei (2016) indicated that CSR is an area of focus for businesses. The CSR concept has a strong history and a future filled with opportunity (Carroll, 2015).

Organizations are placing a higher level of importance on CSR behaviors (Catano \& Morrow Hines, 2016). Chung, Jung, and Young (2018) suggested that CSR could now be considered the new measurement of corporate performance. Oh, Hong, and Hwang (2017) indicated that engaging in CSR 
behaviors can be a primary tool in attaining sustainable growth. However, the value of CSR can be affected through stakeholder perceptions (Hu, Chen, Shao, \& Gao, 2018). To increase consumer value, businesses must understand which dimensions of CSR (economic, legal, ethical, or philanthropic) that various generations perceive to be most significant.

Current literature revealed a need for organizations to understand how stakeholders perceive CSR activities (AL-Eryani, Jönsson, \& McHugh, 2019). Fixen (2018) recommended a need for further research regarding knowledge of CSR perceptions of various generations. Consumers consider factors including the social and environmental impact of a business prior to purchasing goods or services (AL-Eryani et al., 2019). Because each generation may have different attitudes (Kraten, 2016), marketing strategies tailored to specific generational perspective may result in higher profits for businesses. Therefore, understanding generational CSR perspectives is meaningful.

CSR can improve a reputation and increase consumer loyalty, therefore, increasing sales and profits (Creasey, 2015). Additionally, CSR perceptions are linked to consumer purchase and support behaviors (Abdeen, Rajah, \& Gaur, 2016). Therefore, a need exists to understand consumer CSR perspectives on which CSR dimensions are valued most. By understanding generational CSR perspectives, management can create strategies tailored to specific preferences.

The purpose of the following review is to gain a greater understanding of how generational segmentation can be useful in creating tailored CSR marketing strategies. The literature review includes the theoretical foundation, background of the CSR concept, benefits of CSR, importance of understanding generational perspective, and existing research that is relevant to the study.

\section{LITERATURE REVIEW}

\section{Theoretical Foundation}

Carroll (1979) identified the four components of CSR as (a) economic, (b) legal, (c) ethical, and (d) philanthropic responsibilities. Carroll later categorized these dimensions into the pyramid of corporate social responsibility as a way to graphically display dimensions (Schwartz \& Carroll, 2003). Although each CSR dimension includes classification as a separate component, the dimensions overlap (Dusuki \& Yusof, 2008). Carroll (2016) indicated that the four CSR components are empirically related, and yet conceptually independent.

Many theorists use Carroll's dimensions of CSR for research purposes (Schwartz \& Carroll, 2003). According to Yakovleva and Vazquez-Brust (2012), the dimensions are relevant in the business environment. The CSR pyramid is one of the most well-known models to identify a business's social responsibility (Calabrese, Costa, Menichini, Rosati, \& Sanfelice, 2013). According to Carroll (2016), the CSR pyramid is designed to remain relevant as time passes.

\section{Corporate Social Responsibility}

Carroll (2016) indicated that CSR is a concept that continues to develop, and that dozens of definitions exist. No general definition of CSR exists because there are so many perspectives and viewpoints (Aupperle, Hatfield, \& Carroll, 1983). According to Carroll (1991), the lack of a common CSR definition may cause confusion about a business' obligation to society.

While controversial views exist about what constitutes socially responsible behavior, the concept of CSR in modern business is essential. To increase sustainability, organizations must engage in CSR strategy to meet the needs of stakeholders (Hategan et al., 2018). According to Malik, Ali and Anwar (2015), integrating CSR into business strategies can increase the ability of a company to build a competitive advantage.

The concept of CSR is significant, because the CSR choices made by a firm might affect public acceptance (Zhu \& Zhang, 2015). Consumer attitudes toward a business affect purchase intentions (Wu, Tsai, \& Tai, 2016). According to Vidaver-Cohen and Brønn (2015), consumers are more likely to support a firm that engages in CSR related activities. To achieve sustainability, the CSR concept cannot be ignored (Ojasoo, 2016). 


\section{Corporate Social Responsibility Practices}

Being socially responsible is good business practice (DesJardins, 2016). Carroll (2015) indicated that CSR is growing in relevance in modern business practice. Integrating CSR into business practices can contribute to an increase in company value (Hu et al., 2018). Therefore, companies that engage in CSR practices are more profitable (Hategan et al., 2018). Wang, Tong, Takeuchi, and George (2016) indicated that socially responsible practices continue to increase in businesses around the world.

A correlation between CSR practice and performance does exist (Kiessling, Isaksson, \& Yasar, 2016). Businesses can no longer disregard CSR because research indicated that CSR has the potential to influence consumer actions (Creasey, 2015; Chernev \& Blair, 2015). Establishing CSR practices can enhance the ability of an organization to compete, and therefore to increase sustainability (Bernal Conesa, de Nieves Nieto, \& Briones-Peñalver, 2017).

\section{Benefits of Corporate Social Responsibility}

Existing literature suggested that businesses do benefit from engaging in CSR related activities (Joireman, Smith, Liu, \& Arthurs, 2015). According to Wang and Li (2016), companies that engage in social responsibility have higher market value. Implementation of CSR activities may help a business achieve higher levels of success by satisfying the needs and expectations of stakeholders (Oh et al., 2017).

Vidaver-Cohen and Brønn (2015) suggested that CSR practices relate to consumer support. Hameed, Qayyum, and Awan (2018) suggested that consumers are attracted to companies that engage in CSR, and that CSR initiatives influence purchasing intentions. By engaging in CSR initiatives, a business can enhance long-term sustainability (Taran \& Betts, 2015). Financial and social benefits may result from socially responsible behaviors (Jariko, Børsen, \& Jhatial, 2016). CSR can increase sales, lead to higher profits, and increase investor attraction (Creasey, 2015).

\section{Building a Reputation}

Reputation is a valuable asset and should be a main objective for a business (Mokaeane, Moloi, \& Oksiutycz-Munyawiri, 2017). A positive reputation can be used to attract and retain customers (Shabbir, Shariff, Yusof, Salman, \& Hafeez, 2018). Empirical findings indicated that CSR plays a large role in building a strong corporate reputation (Malik et al., 2015). According to Šontaitè-Petkevičienè (2015), CSR is one of the most important determinants of a business' reputation.

Šontaitė-Petkevičienè (2015) indicated that companies who integrate CSR practices into their strategies benefit by achieving a positive reputation. Investors and stakeholders positively value CSR behaviors (Martínez-Ferrero, Banerjee, \& García-Sánchez, 2016). Vidaver-Cohen and Brønn (2015) suggested that CSR does have an impact on the overall support of stakeholders. Stakeholders are more likely to associate with companies that have a reputation for exhibiting strong socially responsible behaviors (Vidaver-Cohen \& Brønn, 2015).

A company that engages in CSR may develop a positive brand image and reputation (Creasey, 2015). Engaging in CSR activities can improve the reputation of a business and increase the ability to remain competitive (Hu et al., 2018). A positive reputation enhances the ability of a business to reach higher levels of performance (Rubtcova \& Pavenkov, 2019).

\section{Building Loyalty}

Chung, Yu, Choi and Shin (2015) indicated that a relationship exists between CSR and customer satisfaction. A commitment to CSR creates greater consumer satisfaction (Park, Kim, \& Kwon, 2017). Increased customer satisfaction increases customer loyalty (Chung et al., 2015).

CSR can be considered an effective approach to protecting and enhancing customer loyalty (Shabbir et al., 2018). Engaging in CSR related initiatives create a sense of trust, which results in loyalty (Iglesias, Markovic, Bagherzadeh, \& Singh, 2018). Chang and Yeh (2017) suggested that customer loyalty results from CSR initiatives that are designed to enhance corporate image. The perception of a positive image can increase customer loyalty (Shabbir et al., 2018). 
The value of a business may increase as a result of increased loyalty from CSR initiatives (Malik et al., 2015). When consumers have a favorable CSR perception, an emotional link to the brand can develop, creating a sense of loyalty (Crespo \& Inacio, 2019). Therefore, CSR is a vital tool for building loyalty in the modern business environment (Fatma, Rahman, \& Khan, 2015). Because consumer perception of CSR initiatives affects loyalty (Tingchi Liu, Anthony Wong, Rongwei, \& Tseng, 2014), an understanding of specific preferences is meaningful.

\section{Importance of Understanding Generational Perspective}

Campbell, Campbell, Siedor and Twenge (2015) indicated that research about the differences between people's perceptions is meaningful, and generational groupings are useful in market segmentation. According to Mothersbaugh, Hawkins, and Kleiser (2020), utilizing age positioning is essential for vast amounts of products. Furthermore, Catano and Morrow Hines (2016) indicated that generational values could differ.

Each generation has different motivators and expectations (Jorge Arturo, José de Jesús, \& Manuel, 2016). Members of a generation may see themselves as a distinct group (Klara, 2016). Campbell et al. (2015) indicated generational groupings are useful when explaining different perceptions. Specific behaviors generally match certain age groups (Chaney, Touzani, \& Ben Slimane, 2017).

According to Mothersbaugh et al. (2020), members of a generation experience a common environment. Each generation has unique characteristics (Fishman, 2016). Knight (2015) suggested that focuses on generational groups are useful in marketing. Therefore, using generations as a segmentation strategy is effective.

\section{Benefits of CSR Strategies Tailored to Generational Preferences}

Building consumer relationships is a marketing priority for businesses (Zhang, Watson, Palmatier, \& Dant, 2016). Morrissey (2015) suggested that the concept of CSR is about focusing on stakeholder perspectives. CSR activities that do not meet consumer expectations may result in unsatisfied consumers (Park, Kim, Oh, \& Chung, 2016).

According to Hillebrand, Driessen, and Koll (2015), responsive thinking helps businesses understand how to respond to stakeholder needs and create value, while also remaining in control of marketing decisions. Because behaviors match with specific age groups, marketing specialists can effectively use generational perspective for segmentation, targeting, and positioning (Chaney et al., 2017). Marketing managers may benefit from focusing on consumer desires (Hillebrand et al., 2015).

With similar histories and shared behaviors, generations serve as unique marketing segments (Mothersbaugh et al., 2020). Marketers realized that each generation has different characteristics and desires, and these differences create the need to tailor marketing strategies to unique generational preferences (Bucuţă, 2015). Because consumers are likely to be unsatisfied when CSR activities do not meet individual expectations (Park et al., 2016), a need for tailored strategies exists.

\section{FINDINGS}

A review of CSR literature suggests that engaging in CSR activities can increase business sustainability (Hategan et al., 2018; Ojasoo, 2016). Wu et al. (2016) identified CSR as a critical component in effective marketing planning. Engaging in CSR behaviors will increase the likelihood of stakeholder support for a business (Vidaver-Cohen \& Brønn, 2015). However, to effectively use CSR to create sustained value, an organization must understand stakeholder perspectives (Oh et al., 2017). Therefore, generational segmentation may be useful in understanding CSR perspectives of specific age groups.

Existing literature largely focuses on the benefits of implementing CSR initiatives. However, little research exists regarding the importance of creating CSR initiatives tailored to consumer desires. According to AL-Eryani et al. (2019), understanding stakeholder perceptions of CSR initiatives is important. This research expands on existing literature by suggesting generational segmentation as a 
method for understanding CSR perceptions. The findings in this literature review suggest that understanding CSR perceptions from a generational perspective can result in significant benefits for a business by creating tailored CSR strategies. This review revealed a need for continued research on the CSR perceptions of various generations.

\section{CONCLUSION}

Understanding consumer perceptions of CSR activities is essential to design initiatives that are meaningful to the customer. Schrempf-Stirling, Palazzo and Phillips (2016) indicated that consumers judge businesses based on the activities that they engage in beyond traditional corporate activities. To operate successfully, businesses must commit to socially responsible practices. According to Malik et al. (2015), integrating CSR into business strategies can increase the ability of a company to build and sustain a competitive advantage.

\section{REFERENCES}

Abdeen, A., Rajah, E., \& Gaur, S. S. (2016). Consumers' beliefs about firm's CSR initiatives and their purchase behaviour. Marketing Intelligence \& Planning, 34(1), 2-18. Retrieved from https://www.emerald.com/insight/publication/issn/0263-4503

AL-Eryani, O., Jönsson, G., \& McHugh, J. (2019). Corporate Social Responsibility (CSR): Using Stakeholder Engagement in Order to Improve Performance. Retrieved from Google Scholar.

Aupperle, K., Hatfield, J. D., \& Carroll, A. B. (1983). Instrument development and application in corporate social responsibility. Academy of Management Proceedings (00650668), 369-373. doi:10.5465/AMBPP.1983.4976378

Bernal Conesa, J. A., de Nieves Nieto, C., \& Briones Peñalver, A. J. (2017). CSR strategy in technology companies: Its influence on performance, competitiveness and sustainability. Corporate social responsibility and environmental management, 24(2), 96-107. doi.org/10.1002/csr.1393

Bucuţă, A. (2015). A review of the specific characteristics of the generation Y consumer. Proceedings of the International Conference Marketing - from Information to Decision, 8, 38. Retrieved from http://www.econ.ubbcluj.ro/mid/

Calabrese, A., Costa, R., Menichini, T., Rosati, F., \& Sanfelice, G. (2013). Turning corporate social responsibility-driven opportunities in competitive advantages: A two-dimensional model. Knowledge \& Process Management, 20(1), 50-58. doi:10.1002/kpm.1401

Campbell, W. K., Campbell, S. M., Siedor, L. E., \& Twenge, J. M. (2015). Generational differences are real and useful. Industrial \& Organizational Psychology, 8(3), 324-331. doi:10.1017/iop.2015.43

Carroll, A. B. (1979). A three-dimensional conceptual model of corporate performance. Academy of Management Review, 4(4), 497-505. doi:10.5465/AMR.1979.4498296

Carroll, A. B. (1991). The pyramid of corporate social responsibility-Toward the moral management of organizational stakeholders. Business Horizons, 34(4), 39-48. Retrieved from http://www.journals.elsevier.com/business-horizons/

Carroll, A. B. (2015). Corporate social responsibility. Organizational dynamics, 44(2), 87-96. Retrieved from https://www.journals.elseavier.com/organizational-dynamics

Carroll, A. B. (2016). Carroll's pyramid of CSR: taking another look. International journal of corporate social responsibility, 1(1), 3. Retrieved from https://jcsr.springeropen.com/

Catano, V. M., \& Morrow Hines, H. (2016). The influence of corporate social responsibility, psychologically healthy workplaces, and individual values in attracting millennial job applicants. Canadian Journal of Behavioural Science / Revue Canadienne Des Sciences Du Comportement, 48(2), 142-154. doi:10.1037/cbs0000036 
Chaney, D., Touzani, M., \& Ben Slimane, K. (2017). Marketing to the (new) generations: summary and perspectives. Journal of Strategic Marketing, 25(3) 179-189. doi.org/10.1080/0965254X.2017.1291173

Chang, Y. H., \& Yeh, C. H. (2017). Corporate social responsibility and customer loyalty in intercity bus services. Transport Policy, 59, 38-45. doi.org/10.1016/j.tranpol.2017.07.001

Chernev, A., \& Blair, S. (2015). Doing well by doing good: The benevolent halo of corporate social responsibility. Journal of Consumer Research, 41(6), 1412-1425. doi:10.1086/680089

Chung, C., Jung, S., \& Young, J. (2018). Do CSR activities increase firm value? Evidence from the Korean market. Sustainability, 10(9), 3164. doi.org/10.3390/su10093164

Chung, K. H., Yu, J. E., Choi, M. G., \& Shin, J. I. (2015). The effects of CSR on customer satisfaction and loyalty in China: the moderating role of corporate image. Journal of Economics, Business and Management, 3(5), 542-547. Retrieved from http://www.joebm.com/

Creasey, D. (2015). Corporate responsibility: You can't afford to ignore it. Governance Directions, 67(3), 161-163. Retrieved from http://www.copyright.com.au

Crespo, C. F., \& Inacio, N. (2019). The influence of corporate social responsibility associations on consumers' perceptions towards global brands. Journal of Strategic Marketing, 27(8), 679-695. https://doi.org/10.1080/0965254X.2018.1464497

DesJardins, J. (2016). Is it Time to Jump off the Sustainability Bandwagon? Business Ethics Quarterly, 26(1), 117. doi:10.1017/beq.2016.12

Dusuki, A. W., \& Yusof, T. M. (2008). The pyramid of corporate social responsibility model: Empirical evidence from Malaysian stakeholder perspectives. Malaysian Accounting Review, 7(2), 29-54. Retrieved from http://www.maref.org.my/publication/malaysian-accounting-reviews.html

Esmaeilpour, M., \& Barjoei, S. (2016). The Impact of Corporate Social Responsibility and Image on Brand Equity. Global Business \& Management Research, 8(3), 55-66. Retrieved from http://www.gbmr.ioksp.com/

Fatma, M., Rahman, Z., \& Khan, I. (2015). Building company reputation and brand equity through CSR: the mediating role of trust. International Journal of Bank Marketing, 33(6), 840-856. Retrieved from https://www.emerald.com/insight/publication/issn/0265-2323

Fixen, M. (2018). Comparing the Corporate Social Responsibility Perceptions of Generation X. Journal of Leadership, Accountability and Ethics, 15(3). doi: https://doi.org/10.33423/jlae.v15i3.1247

Fishman, A. A. (2016). How generational differences will impact America's aging workforce: strategies for dealing with aging Millennials, Generation X, and Baby Boomers. strategic HR Review, 15(6), 250-257. doi.org/10.1108/SHR-08-2016-0068

Hameed, F., Qayyum, A., \& Awan, Y. (2018). Impact of Dimensions of CSR on Purchase Intention with Mediating Role of Customer Satisfaction, Commitment and Trust. Pakistan Business Review, 20(1), 13-30. Retrieved from https://journals.iobmresearch.com/index.php/PBR

Hategan, C. D., Sirghi, N., Curea-Pitorac, R. I., \& Hategan, V. P. (2018). Doing well or doing good: The relationship between corporate social responsibility and profit in Romanian companies. Sustainability, 10(4), 1041. doi.org/10.3390/su10041041

Hillebrand, B., Driessen, P., \& Koll, O. (2015). Stakeholder marketing: theoretical foundations and required capabilities. Journal of the Academy of Marketing Science, 43(4), 411-428. doi:10.1007/s11747-015-0424-y

Hu, Y., Chen, S., Shao, Y., \& Gao, S. (2018). CSR and firm value: Evidence from China. Sustainability, 10(12), 4597. doi.org/10.3390/su10124597

Iglesias, O., Markovic, S., Bagherzadeh, M., \& Singh, J. J. (2018). Co-creation: A key link between corporate social responsibility, customer trust, and customer loyalty. Journal of Business Ethics, 1-16. Retrieved from https://link.springer.com/journal/10551

Jariko, M. A., Børsen, T., \& Jhatial, A. A. (2016). Corporate social responsibility in Pakistan: Its status and ways forward. International Journal of Business \& Public Administration, 13(1), 1-20. Retrieved from http://www.iabpad.com/journals/ 
Joireman, J., Smith, D., Liu, R. L., \& Arthurs, J. (2015). It's all good: Corporate social responsibility reduces negative and promotes positive responses to service failures among value-aligned customers. Journal of Public Policy \& Marketing, 34(1), 32-49. Retrieved from http://www.ama.org/

Jorge Arturo, H. P., José de Jesús, E. M., \& Manuel, A. A. (2016). Diferencias en los motivadores y los valores en el trabajo de empleados en empresas maquiladoras / Differences in motivators and values in the work of maquiladora industry employees. Contaduría Y Administración, (1), 58. doi:10.1016/j.cya.2015.09.003

Kiessling, T., Isaksson, L., \& Yasar, B. (2016). Market orientation and CSR: Performance implications. Journal of Business Ethics, 137(2), 269-284. doi.org/10.1007/s1055

Klara, R. (2016). The invisible generation. Adweek, 57(12), 20-23. Retrieved from http://www.adweek.com/

Knight, L. (2015). Taking Millennials at Face Value Will Derail Your Marketing Efforts to Reach Them. Adweek, 1. Retrieved from http://www.adweek.com/

Kraten, M. (2016). Integrated Reporting and Generational Priorities. CPA Journal, 86(8), 10-11.

Retrieved from https://www.nysscpa.org/news/publications/the-cpa-journal/issue

Liu, M. T., Wong, I. A., Rongwei, C., \& Tseng, T. H. (2014). Do perceived CSR initiatives enhance customer preference and loyalty in casinos? International Journal of Contemporary Hospitality Management, 26(7), 1024-1045. Retrieved from https://www.emerald.com/insight/publication/issn/0959-6119

Malik, M. S., Ali, H., \& Anwar, I. (2015). Corporate social responsibility and organizational performance: Empirical evidence from banking sector. Pakistan Journal of Commerce \& Social Sciences, 9(1), 241-247. Retrieved from http://www.jespk.net

Martínez-Ferrero, J., Banerjee, S., \& García-Sánchez, I. (2016). Corporate social responsibility as a strategic shield against costs of earnings management practices. Journal of Business Ethics, 133(2), 305-324. doi:10.1007/s10551-014-2399-x

Mokaeane, S. B., Moloi, K. C., \& Oksiutycz-Munyawiri, A. (2017). Corporate reputation management: A case study of the Emfuleni Local Municipality in South Africa. Journal of Public Administration, 52(2), 381-392. Retrieved from https://journals.co.za/content/journal/jpad

Morrissey, D. J. (2015). The riddle of shareholder rights and corporate social responsibility. Brooklyn Law Review, 80(2), 353-395. Retrieved from http://www.brooklaw.edu

Mothersbaugh, D. L., Hawkins, D. I., \& Kleiser, S. B. (2020). Consumer behavior: Building marketing strategy (14th ed.). New York, NY: McGraw-Hill.

Oh, S., Hong, A., \& Hwang, J. (2017). An analysis of CSR on firm financial performance in stakeholder perspectives. Sustainability, 9(6), 1023. Retrieved from https://doi.org/10.3390/su9061023

Ojasoo, M. (2016). CSR reporting, stakeholder engagement and preventing hypocrisy through ethics audit. Journal of Global Entrepreneurship Research, 6(1), 14. Retrieved from https://journaljger.springeropen.com/

Park, E., Kim, K. J., \& Kwon, S. J. (2017). Corporate social responsibility as a determinant of consumer loyalty: An examination of ethical standard, satisfaction, and trust. Journal of Business Research, 76, 8-13. doi.org/10.1016/j.jbusres.2017.02.017

Park, G., Kim, W., Oh, J., \& Chung, K. (2016). Study on the structural relationship among CSR motivations, CSR activities, trust and loyalty: Focused on Korea retailing sector. International Journal of u-and e-Service, Science and Technology, 9(5), 169-180. Retrieved from https:/www.scimagojr.com/journalsearch.php?q=21100873118\&tip=sid\&exact=no

Rubtcova, M., \& Pavenkov, O. (2019, April). Development of Positive Image and Business Reputation of the Company. In The IIER-517th International Conference on Law and Political Science (ICLPS) CHENNAI, Tamil Nadu, India 23rd-24th April. Retrieved from https://www.allconferencealert.com/event-detail.html?ev_id=198342\&eventname=

Schrempf-Stirling, J., Palazzo, G., \& Phillips, R. A. (2016). Historic corporate social responsibility. Academy of Management Review, 41(4), 700-719. doi.org/10.5465/amr.2014.0137 
Schwartz, M. S., \& Carroll, A. B. (2003). Corporate social responsibility: A three-domain approach. Business Ethics Quarterly, 13(4), 503-530. Retrieved from https://www.cambridge.org/core/journals/business-ethics-quarterly

Shabbir, M. S., Shariff, M. N. M., Yusof, M. S. B., Salman, R., \& Hafeez, S. (2018). Corporate social responsibility and customer loyalty in Islamic banks of Pakistan: a mediating role of brand image. Academy of Accounting and Financial Studies Journal. Retrieved from https://www.abacademies.org/journals/academy-of-accounting-and-financial-studies-journalhome.html

Šontaitė-Petkevičienè, M. (2015). CSR reasons, practices and impact to corporate reputation. ProcediaSocial and Behavioral Sciences, 213, 503-508. doi.org/10.1016/j.sbspro.2015.11.441

Taran, Z., \& Betts, S. (2015). Corporate social responsibility and conflicting stakeholder interests: using matching and advocacy approaches to align initiatives with issues. Journal of Legal, Ethical \& Regulatory Issues, 18(2), 55-61. Retrieved from http://www.alliedacademies.org/legal-ethicaland-regulatory-issues/

Vidaver-Cohen, D., \& Brønn, P. (2015). Reputation, responsibility, and stakeholder support in Scandinavian firms: A comparative analysis. Journal of Business Ethics, 127(1), 49-64. doi:10.1007/s10551-013-1673-7

Wang, H., Tong, L., Takeuchi, R., \& George, G. (2016). Corporate social responsibility: An overview and new research directions: Thematic issue on corporate social responsibility. doi.org/10.5465/amj.2016.5001

Wang, K., \& Li, D. (2016). Market Reactions to the First-Time Disclosure of Corporate Social Responsibility Reports: Evidence from China. Journal of Business Ethics, 138(4), 661-682. doi:10.1007/s10551-015-2775-1

Wu, T. J., Tsai, H. T., \& Tai, Y. N. (2016). Would corporate social responsibility affect consumers' attitudes towards brand and purchase behavior? Buyer-seller guanxi as the moderator. Revista de Cercetare si Interventie Sociala, 53, 272-287. Retrieved from https://www.ceeol.com/search/journal-detail?id=937

Yakovleva, N., \& Vazquez-Brust, D. (2012). Stakeholder perspectives on CSR of mining MNCs in Argentina. Journal of Business Ethics, 106(2), 191-211. doi: 10.1007/s10551-011-0989-4

Zhang, J. Z., Watson, G. F., IV., Palmatier, R. W., \& Dant, R. P. (2016). Dynamic Relationship Marketing. Journal of Marketing, 80(5), 53-90. doi.10.1509/jm.15.0066

Zhu, Q., \& Zhang, Q. (2015). Evaluating practices and drivers of corporate social responsibility: The Chinese context. Journal of Cleaner Production, 100, 315-324. doi.org/10.1016/j.jclepro.2015.03.053 